\title{
Penentuan Derajat Optimum Interpolasi pada Metode Lagrange dan Metode Newton Gregory dalam Mengestimasi Kasus Pasien Sembuh dari Covid-19 di Indonesia
}

\author{
Muhammad Julian ${ }^{1, a)}$, Lukita Ambarwati ${ }^{1, b)}$, Yudi Mahatma ${ }^{1, c)}$ \\ ${ }^{1}$ Program Studi Matematika,Fakultas Matematika dan Ilmu Pengetahuan Alam,Universitas Negeri Jakarta

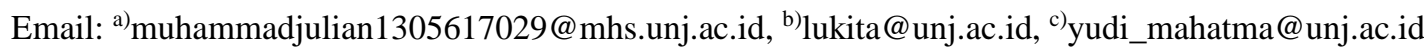

\begin{abstract}
Estimation is one method for approximation. The estimation method is the polynomial interpolation. Once of polynomial interpolation are Lagrange method and Newton Gregory method. In several references, the degrees of interpolation which is used on the Lagrange method or Newton Gregory method depends on the numbers of data. This paper was created to knowing the optimum degrees to interpolate 61 numbers of data. In this paper, points are determined to interpolate so that formed intervals of equal length. As for the degrees to be tested, namely degrees 2,4,5,10, and 20. Based on MAPE and MSE values for degree 2 are lower than degrees 4,5,10 and 20 in both methods so that the interpolation of the Lagrange and Newton Gregory degrees 2 is better than degrees 4,5,10, and 20.
\end{abstract}

Keywords: Interpolation, Estimation, Lagrange, Newton Gregory Forward, Newton Gregory Backward.

\begin{abstract}
Abstrak
Estimasi merupakan salah satu metode untuk menduga suatu data. Metode estimasi antara lain yaitu interpolasi polinomial. Salah satu metode interpolasi polinomial yaitu metode Lagrange dan Newton Gregory. Dalam beberapa referensi, derajat interpolasi yang digunakan pada interpolasi Lagrange atau Newton Gregory bervariasi tergantung banyaknya data yang digunakan. Penelitian ini dilakukan untuk mengetahui derajat optimum yang akan digunakan untuk menginterpolasi 61 titik data. Dalam penelitian ini, titik-titik yang akan diinterpolasi dipilih sedemikian sehingga terbentuk selang-selang yang panjangnya sama. Adapun derajat yang akan diuji adalah adalah derajat 2,4,5,10, dan 20. Nilai MAPE dan MSE untuk derajat 2 lebih rendah dibanding derajat 4,5,10, dan 20 pada kedua metode sehingga interpolasi metode Lagrange maupun Newton Gregory derajat 2 lebih baik dibanding derajat 4,5,10, dan 20.
\end{abstract}

Kata-kata kunci: Interpolasi, Estimasi,Lagrange, Newton Gregory Forward, Newton Gregory Backward

\section{PENDAHULUAN}

Pandemi Covid-19 membuat tahun 2020 menjadi tahun yang berat bagi negara-negara di dunia khususnya Indonesia. Pemerintah dalam upayanya menekan penyebaran virus Covid-19 di Indonesia menerapkan sistem Pembatasan Sosial Berskala Besar (PSBB) (Rahmatullah, 2020) 
(Hakimah, Kurniawan, dan Muhima, 2020) telah membahas mengenai "Pemodelan Jumlah Kasus Baru Covid-19 di Masa Kenormalan Baru Menggunakan Metode Pencocokan Kurva". Metode yang digunakan salah satunya adalah metode interpolasi polinomial Lagrange dan polinomial interpolasi Newton berderajat 2,3, dan 4 untuk data periode 1 Juni 2020 sampai 2 Agustus 2020. Hasil yang diperoleh yaitu nilai MAPE dan RMSE untuk polinom Lagrange derajat 4 lebih rendah dari polinom Lagrange berderajat 2 dan 3. Sementara itu, nilai MAPE pada polinom Newton derajat 4 lebih rendah dari polinom Newton derajat 2 dan 3 tetapi nilai RMSE pada polinom Newton derajat 3 lebih rendah dari polinom Newton derajat 2 dan 4. Sehingga pada penelitian tersebut diperoleh kesimpulan bahwasanya bentuk polinom Lagrange derajat 4 dan polinom Newton derajat 3 dan 4 lebih merepresentasikan model matematika jumlah kasus baru Covid-19. Hal ini menunjukkan bahwa semakin besar derajat interpolasi yang digunakan belum tentu membuat hasil prediksi atau estimasi interpolasi semakin akurat karena nilai RMSE pada polinom Newton derajat 3 dalam penelitian tersebut lebih rendah daripada derajat 2 dan derajat 4.

Berdasarkan uraian, pada artikel ini akan dibahas mengenai penentuan derajat optimum interpolasi pada metode Lagrange dan metode Newton Gregory dalam mengestimasi kasus pasien sembuh dari Covid-19 di Indonesia. Optimum menurut Kamus Besar Bahasa Indonesia adalah kondisi yang terbaik. Pada penelitian ini, penentuan derajat interpolasi yang optimum akan ditentukan dengan melihat nilai MAPE dan MSE terendah pada masing-masing metode interpolasi. MAPE dan MSE akan diperoleh dari perhitungan metode Lagrange dan metode Newton Gregory. Metode Lagrange dan Newton Gregory digunakan dalam penelitian ini karena data yang digunakan dalam penelitian ini merupakan data jumlah kasus pasien sembuh dari Covid-19 di Indonesia per hari periode 1 September 2020 - 31 Oktober 2020. Adapun tujuan dari penelitian ini untuk mengetahui penerapan interpolasi Lagrange dan Newton Gregory khususnya Newton Gregory Forward dan Backward pada kasus pasien sembuh dari Covid-19 di Indonesia, serta mengetahui bagaimana memperoleh derajat yang optimum pada interpolasi pada kasus pasien sembuh dari Covid-19 di Indonesia.

\section{LANDASAN TEORI}

\section{Interpolasi Polinomial}

\section{Definisi}

Menurut (Astuti, Sudarwanto, dan Ambarwati, 2018) dan (Herstein, 1996), jika suatu polinomial $P_{k}(m)$ berderajat kurang dari sama dengan $k$, maka bentuk baku fungsi polinomial yaitu

$$
P_{k}(m)=a_{n}+a_{1} m+\cdots+a_{k} m^{k} ; a_{k} \neq 0
$$

dimana $a_{0}, a_{1}, \ldots, a_{k}$ merupakan koefisien elemen bilangan rill. Polinomial tersebut tepat berderajat $k$ jika koefisien tidak bernilai nol (Astuti, Sudarwanto, dan Ambarwati, 2018). Misalkan diberikan $\left(m_{0}, n_{0}\right),\left(m_{1}, n_{1}\right), \ldots,\left(m_{k}, n_{k}\right)$ dan $m=a$ sedemikian sehingga $n=P_{k}(a)$, maka terdapat kemungkinan letak nilai $m=a$ sebagai berikut.

1. Jika $m=a$ berada di dalam interval titik data yaitu $m_{0}<a<m_{k}$, maka $n=P_{k}(a)$ disebut dengan nilai interpolasi.

2. Jika $m=a$ berada di luar interval titik data yaitu $a<m_{0}$ atau $a>m_{k}$, maka $n=P_{k}(a)$ disebut dengan nilai ekstrapolasi.

\section{Interpolasi Linear}

Interpolasi linear merupakan interpolasi yang digunakan untuk menginterpolasi dua pasang titik dengan memanfaatkan garis lurus. Berdasarkan (2.1), persamaan interpolasi linear adalah sebagai berikut.

$$
P_{1}(m)=n_{0}+\frac{n_{1}-n_{0}}{m_{1}-m_{\mathrm{n}}}\left(m-m_{0}\right)
$$




\section{Interpolasi Lagrange}

Interpolasi Lagrange merupakan perluasan dari interpolasi polinomial. Berdasarkan (2.2) dapat diperoleh persamaan interpolasi Lagrange sebagai berikut. Untuk polinomial Lagrange berderajat kurang dari sama dengan $k$ dengan $k+1$ pasang titik data $\left(m_{0}, n_{0}\right),\left(m_{1}, n_{1}\right), \ldots,\left(m_{k}, n_{k}\right)$ adalah

dengan

$$
P_{k}(m)=\sum_{i=0}^{k} f\left(m_{i}\right) L_{i}(m)
$$

$$
\begin{gathered}
L_{i}(m)=\frac{\left(m-m_{0}\right)\left(m-m_{1}\right)\left(m-m_{2}\right) m\left(m-m_{k}\right)}{\left(m_{i}-m_{n}\right)\left(m_{i}-m_{1}\right)\left(m_{i}-m_{n}\right) \omega\left(m_{i}-m_{k}\right)} \\
L_{i}(m)=\prod_{j=0, j \neq i}^{k} \frac{m-m_{j}}{m_{i}-m_{i}} ; f\left(m_{i}\right)=n_{i}
\end{gathered}
$$

\section{Polinomial Newton Gregory}

Polinomial Newton Gregory merupakan kasus khusus dari polinomial Newton. Titik-titik data pada polinomial Newton Gregory berjarak sama. Karena titik-titik data berjarak sama, maka formulasi yang dibentuk oleh polinomial Newton Gregory menjadi lebih sederhana (Wahyuni dan Simamora, 2019). Adapun persamaan interpolasi polinomial Newton Gregory Forward $\left(N G F_{k}\right)$ dan Newton Gregory Backward $\left(N G B_{k}\right)$ sebagai berikut.

$$
\begin{gathered}
N G F_{k}(m)=n_{0}+\frac{\Delta n_{0}}{1 !} s+\frac{\Delta^{n} n_{0}}{2 !} s(s-1)+\frac{\Delta^{a} n_{0}}{3 !} s(s-1)(s-2)+\cdots \\
+\frac{\Delta^{k} n_{0}}{k !} s(s-1)(s-2) \ldots(s-(k-1))
\end{gathered}
$$

dengan $s=\frac{m-m_{0}}{h}$ dan $h$ jarak antar titik bernilai konstan.

$$
\begin{gathered}
N G B_{k}(m)=n_{0}+\frac{\nabla n_{0}}{1 !} s+\frac{\nabla^{2} n_{0}}{2 !} s(s+1)+\frac{\nabla^{\mathrm{g}} n_{0}}{3 !} s(s+1)(s+2)+\cdots \\
+\frac{\nabla^{k} n_{0}}{k !} s(s+1)(s+2) \ldots(s+(k-1))
\end{gathered}
$$

dengan $s=\frac{m-m_{0}}{h}$ dan $h$ jarak antar titik bernilai konstan.

\section{Mean Absolute Percentage Error (MAPE)}

Mean Absolute Percentage Error (MAPE) adalah jumlah dari error mutlak setiap data dibagi dengan nilai prediksi yang kemudian hasilnya dibagi dengan banyaknya data yang digunakan untuk analisis. MAPE dapat diformulasikan sebagai berikut

$$
M A P E=\frac{1}{k} \sum_{i=1}^{k} \frac{\left\|e_{i}\right\|}{n_{i}} \times 100 \% ; e_{i}=n_{i}-\hat{n}_{i}
$$

dimana $n_{i}$ adalah nilai aktual dan $\hat{n}_{i}$ adalah nilai hasil estimasi. Berdasarkan (Warmansyah dan Hilpiah, 2019) interpretasi nilai MAPE dapat dinyatakan pada tabel berikut.

TABEL 1: Interpretasi nilai MAPE

\begin{tabular}{cc}
\hline MAPE $($ dalam $\%)$ & Interpretasi \\
\hline MAPE $\leq 10$ & Sangat Baik \\
\hline $10<$ MAPE $\leq 20$ & Baik \\
\hline $20<$ MAPE $\leq 50$ & Cukup Baik \\
\hline MAPE $>50$ & Kurang \\
\hline
\end{tabular}

\section{Mean Squared Error (MSE)}

MSE merupakan penjumlahan dari error kuadrat atau selisih dari data rill dengan nilai prediksi yang dikuadratkan dibagi dengan banyaknya data yang digunakan untuk analisis. MSE dapat 
diformulasikan sebagai berikut

$$
\text { MSE }=\frac{1}{k} \sum_{i=1}^{k} e_{i}^{2} ; e_{i}=n_{i}-\hat{n}_{i}
$$

dimana $n_{i}$ adalah nilai aktual dan $\hat{n}_{i}$ adalah nilai hasil estimasi.

\section{HASIL DAN PEMBAHASAN}

Pokok bahasan penelitian ini tentang penentuan derajat optimum interpolasi pada metode Lagrange, Newton Gregory Forward, dan Newton Gregory Backward dengan data uji menggunakan data kasus pasien sembuh dari Covid-19 di Indonesia.

Data bersifat open source diperoleh dari laman Satuan Tugas Penanganan Covid-19 Republik Indonesia (Satuan Tugas Penanganan Covid-19 Republik Indonesia, 2020) pada kasus pasien sembuh dari Covid-19 di Indonesia per 1 September 2020 - 31 Oktober 2020 sehingga banyaknya data berjumlah 61 data dan dianalisis dengan menggunakan software Microsoft Excel.

Pada penelitian ini, bentuk polinomial yang akan dibentuk yaitu polinomial berderajat $2,4,5,10$, dan 20 pada masing-masing metode interpolasi berdasarkan data uji yang terdapat pada tabel (2). Derajat dipilih didasari oleh pembagian selang interpolasi secara homogen yang berarti jarak antar titik-titik data adalah sama. Titik yang digunakan untuk menginterpolasi dan titik yang akan diinterpolasi pada masing-masing metode sama. Sebagai contoh, jika dipilih derajat selain 2,4,5,10, dan 20 yaitu 3 untuk diterapkan pada tabel (2), titik uji yang dipilih yaitu hari ke-1,4,7,10 lalu hari ke-10,13,16,19 dan di selang terakhir hari ke-55,58,61 kekurangan data.

Data yang digunakan untuk interpolasi dengan derajat 2 adalah data hari ke-1, 4, 7 untuk menginterpolasi hari ke-2, 3, 5, 6. Kemudian data hari ke-7, 10, 13 untuk menginterpolasi hari ke-8, 9, 11, 12 dan seterusnya hingga data hari ke- 55, 58, 61 untuk menginterpolasi hari ke-56, 57, 59, 60.

Data yang digunakan untuk interpolasi dengan derajat 4 adalah data hari ke-1, 4, 7, 10, 13 untuk menginterpolasi hari ke-2, 3, 5, 6, 8, 9, 11, 12. Kemudian data hari ke-13, 16, 19, 22, 25 untuk menginterpolasi hari ke-14, 15, 17, 18, 20, 21, 23, 24 dan seterusnya hingga hari ke-49, 52, 55, 58, 61 untuk menginterpolasi hari ke-50, 51, 53, 54, 56, 57, 59, 60.

Data yang digunakan untuk interpolasi dengan derajat 5 adalah data hari ke-1, 4, 7, 10, 13, 16 untuk menginterpolasi hari ke-2, 3, 5, 6, 8, 9, 11, 12, 14, 15. Kemudian data hari ke-16, 19, 22, 25, 28,31 untuk menginterpolasi hari ke-17, 18, 20, 21, 23, 24, 26, 27, 29, 30 dan seterusnya hingga hari ke-46, 49, 52, 55, 58, 61 untuk menginterpolasi hari ke-47, 48, 50, 51, 53, 54, 56, 57, 59, 60.

Data yang digunakan untuk interpolasi dengan derajat 10 adalah data hari ke-1, 4, 7, .., 28, 31 untuk menginterpolasi hari ke-2, 3, 5, 6, .., 29, 30 dan hari ke-31, 34, .., 58, 61 untuk menginterpolasi hari ke-32, 33, ... 59, 60. Data yang digunakan untuk interpolasi dengan derajat 20 adalah data hari ke-1, 4, 7, 10, ..., 61 untuk menginterpolasi hari ke-2, 3, 5, 6, 8, 9, 11, 12,..., 59, 60.

TABEL 2: Data Uji

\begin{tabular}{cccccc}
\hline No & Tanggal & Pasien Sembuh & No & Tanggal & Pasien Sembuh \\
\hline 1 & 1 -Sep-20 & 2098 & 31 & 1 -Oct-20 & 3540 \\
\hline 4 & $4-$ Sep-20 & 2126 & 34 & $4-O c t-20$ & 3401 \\
\hline 7 & $7-$ Sep-20 & 2077 & 37 & $7-O c t-20$ & 3854 \\
\hline 10 & $10-$ Sep-20 & 2310 & 40 & $10-$ Oct-20 & 3814 \\
\hline 13 & $13-$ Sep-20 & 2552 & 43 & $13-$ Oct-20 & 4777 \\
\hline 16 & $16-$ Sep-20 & 3036 & 46 & $16-$ Oct-20 & 3883 \\
\hline 19 & $19-$ Sep-20 & 3576 & 49 & $19-$ Oct-20 & 3919 \\
\hline 22 & $22-$ Sep-20 & 3501 & 52 & $22-O c t-20$ & 3497 \\
\hline 25 & $25-$ Sep-20 & 4343 & 55 & $25-O c t-20$ & 4545 \\
\hline 28 & $28-$ Sep-20 & 3856 & 58 & $28-O c t-20$ & 3545 \\
\hline
\end{tabular}




\section{Metode Interpolasi Lagrange}

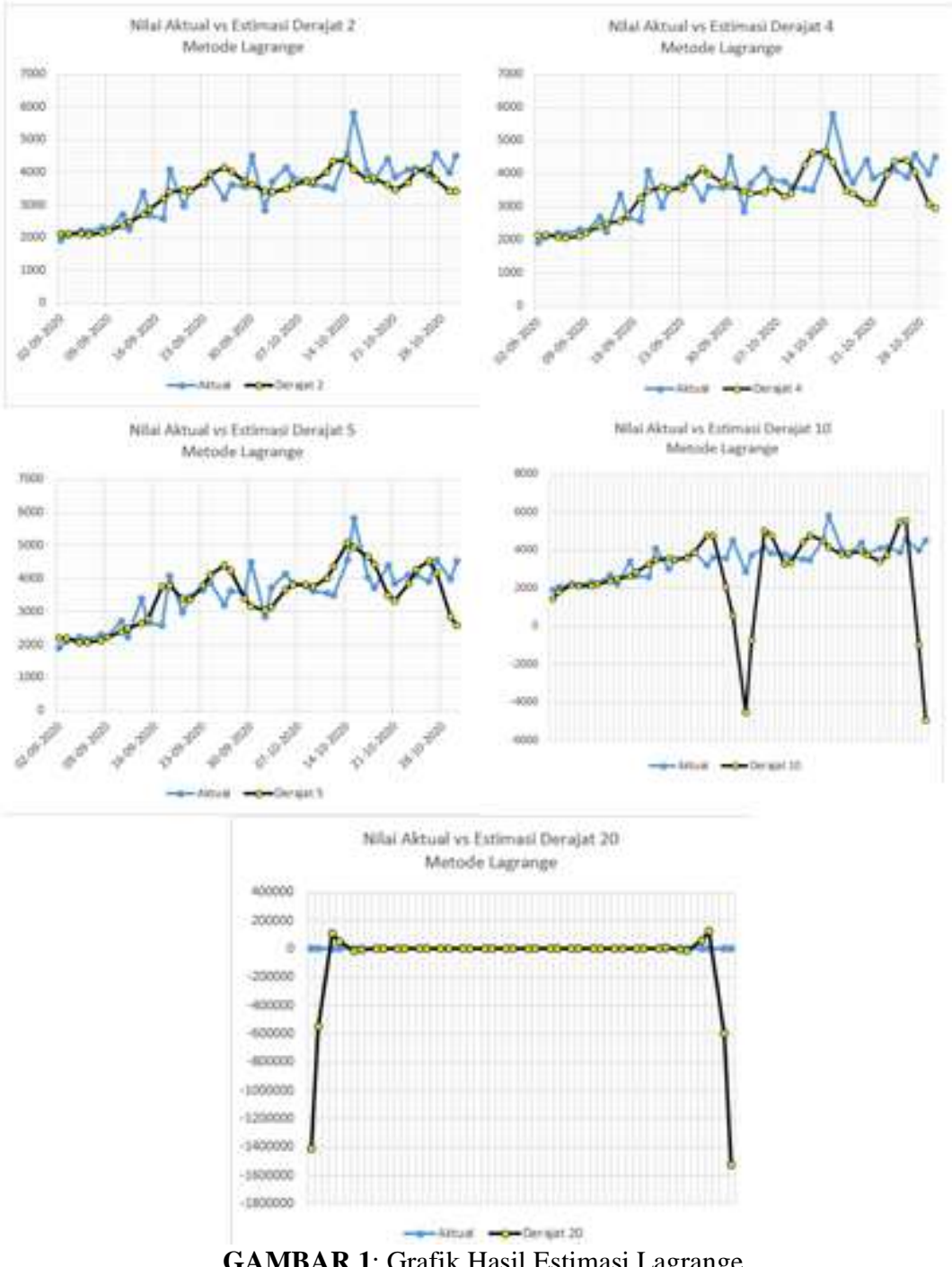

GAMBAR 1: Grafik Hasil Estimasi Lagrange

TABEL 3: Nilai MAPE dan MSE Metode Lagrange

\begin{tabular}{ccc}
\hline Metode Lagrange & MAPE $(\%)$ & MSE \\
\hline Derajat 2 & 10.9580964272568 & 297127.166666667 \\
\hline Derajat 4 & 13.4054649345287 & 395505.513259327 \\
\hline Derajat 5 & 13.3415306375691 & 411528.193044148 \\
\hline Derajat 10 & 33.8830332806182 & 5595460.99800393 \\
\hline Derajat 20 & 4084.79483930204 & 125974056751.287 \\
\hline
\end{tabular}




\section{Interpolasi Newton Gregory Forward}

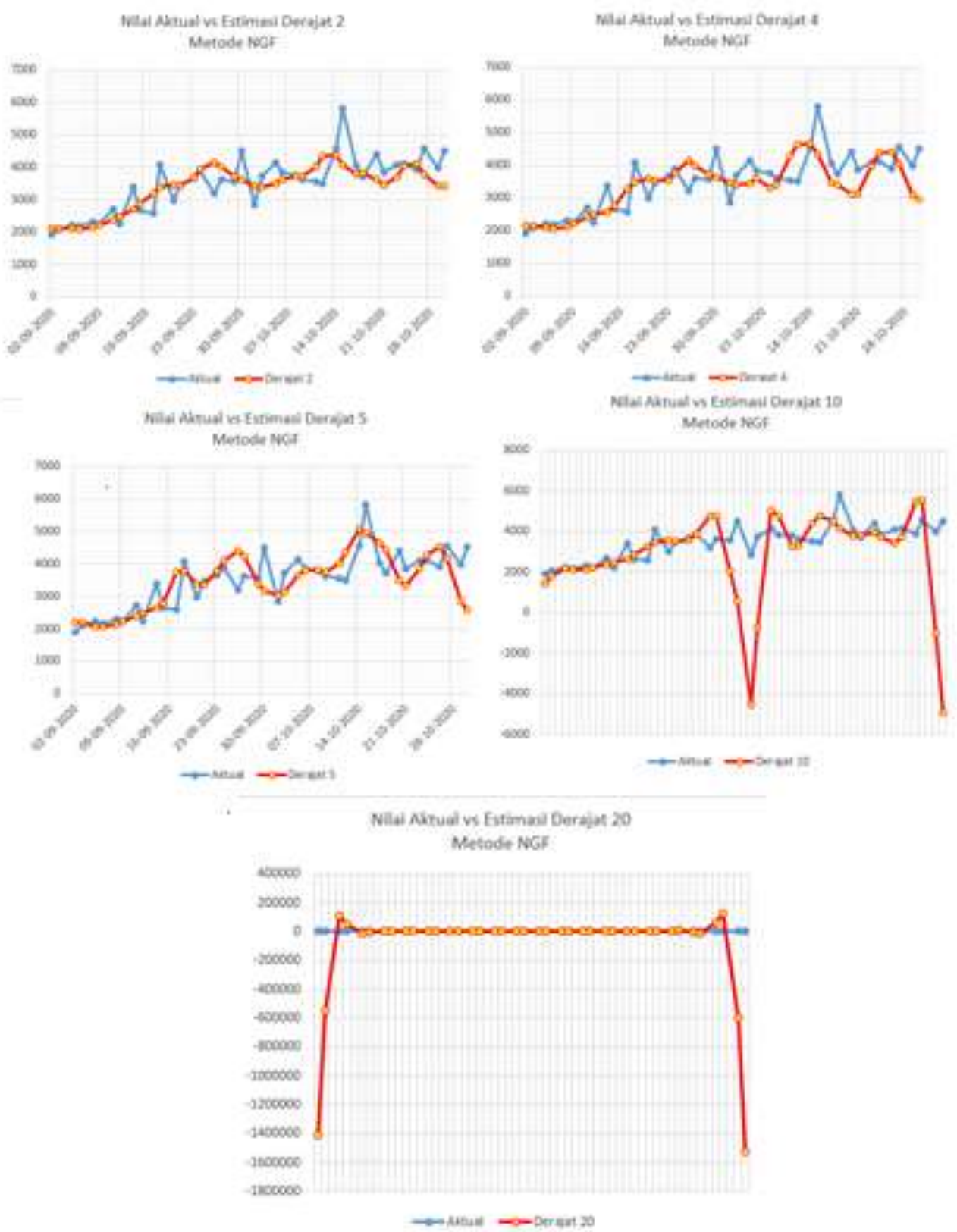

GAMBAR 2: Grafik Hasil Estimasi Newton Gregory Forward

TABEL 4: Nilai MAPE dan MSE Metode Newton Gregory Forward

\begin{tabular}{|c|c|c|}
\hline Metode NGF & MAPE $(\%)$ & MSE \\
\hline Derajat 2 & 10.9580964277651 & 297127.166688866 \\
\hline Derajat 4 & 13.4054649340728 & 395505.513272552 \\
\hline Derajat 5 & 13.3415321833751 & 411528.202951462 \\
\hline Derajat 10 & 33.8830332824437 & 5595460.99826289 \\
\hline Derajat 20 & 4084.79483958871 & 125974056753.389 \\
\hline
\end{tabular}




\section{Interpolasi Newton Gregory Backward}

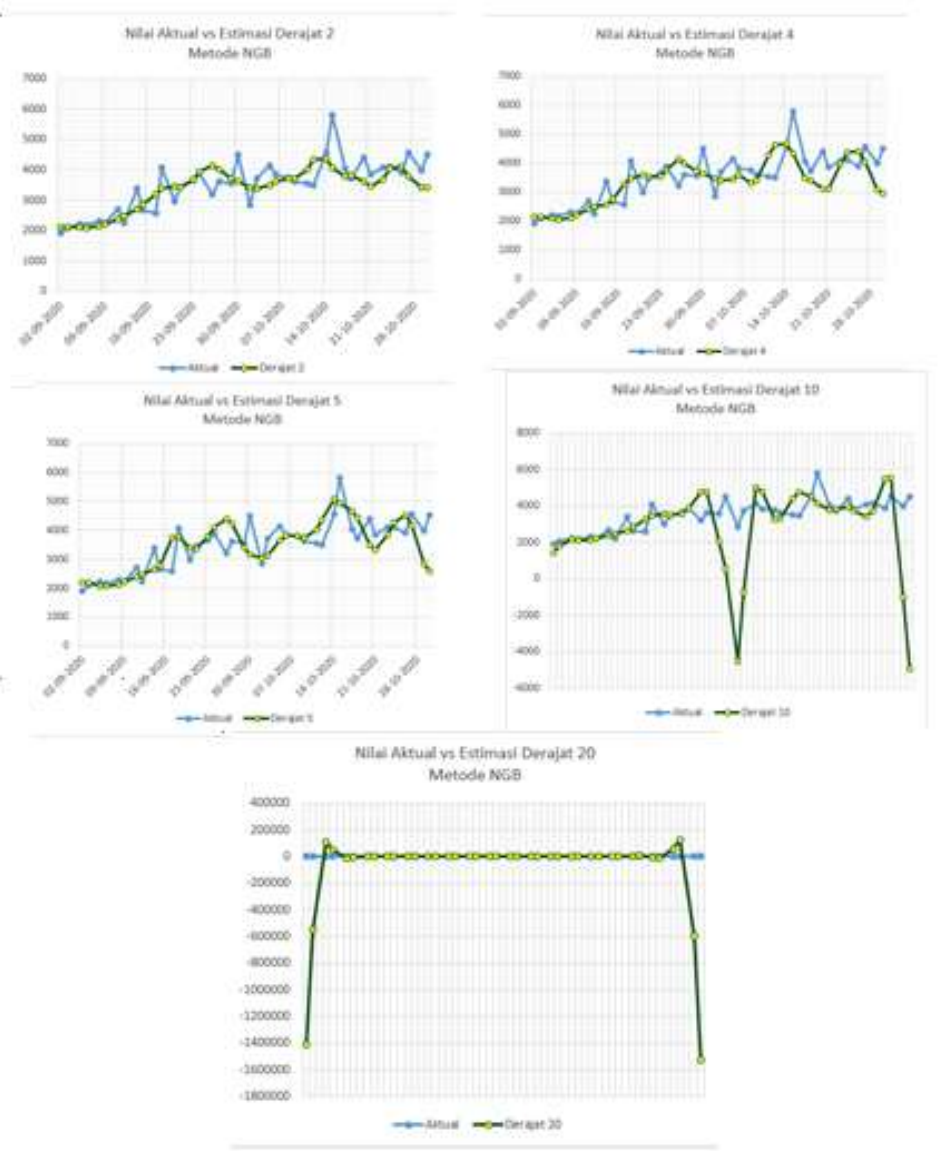

GAMBAR 3: Grafik Hasil Estimasi Newton Gregory Backward

TABEL 5: Nilai MAPE dan MSE Metode Newton Gregory Backward

\begin{tabular}{|c|c|c|}
\hline Metode NGB & MAPE(\%) & MSE \\
\hline Derajat 2 & 10.9580964272568 & 297127.166666667 \\
\hline Derajat 4 & 13.4054649345287 & 395505.513259327 \\
\hline Derajat 5 & 13.3415306375691 & 411528.193044148 \\
\hline Derajat 10 & 33.8830332806182 & 5595460.99800393 \\
\hline Derajat 20 & 4084.79483921061 & 125974056746.703 \\
\hline
\end{tabular}

Ditinjau dari gambar 1, gambar 2, dan gambar 3, hasil yang diperoleh secara visualisasi grafik pada setiap metode cenderung mirip. Dari grafik di atas dapat diketahui bahwa baik metode Lagrange, Metode Newton Gregory Forward, ataupun Newton Gregory Backward pada derajat 10 dan derajat 20 memiliki beberapa nilai estimasi yang negatif dari hasil perhitungan. Sementara itu, nilai estimasi derajat 2, 4, dan 5 pada ketiga metode tersebut tidak ada yang bernilai negatif.

Berdasarkan grafik hasil perhitungan di atas yaitu derajat 2, 4, dan 5 pada ketiga metode lebih baik dari derajat 10 dan derajat 20 karena tidak terdapat nilai estimasi yang bernilai negatif. Berdasarkan tabel MAPE dan MSE pada setiap metode, nilai MAPE dan MSE berderajat 2 pada ketiga metode lebih rendah daripada derajat lainnya.

Nilai MAPE derajat 20 pada ketiga metode lebih besar dari 50\%. Berdasarkan tabel (1), derajat 20 berada dalam kategori kurang. Nilai MAPE derajat 10 pada ketiga metode berada dalam kategori cukup baik. Sementara itu, Nilai MAPE derajat 2, 4 dan 5 pada ketiga metode berada pada kategori baik. Hal ini menunjukkan bahwa derajat 20 pada ketiga metode kurang efektif digunakan untuk mengestimasi data dalam penelitian ini. 


\section{PENUTUP}

\section{Kesimpulan}

Berdasarkan asumsi dan batasan yang telah dibentuk untuk menginterpolasi 61 titik data kasus pasien sembuh dari Covid-19 di Indonesia periode 1 September 2020 - 31 Oktober 2020 dengan derajat 2,4,5,10,20 maka ketiga metode tersebut dapat digunakan untuk mengestimasi data kasus pasien sembuh dari Covid-19 di Indonesia.

Berdasarkan hasil diatas, nilai MAPE dan MSE terendah pada metode Lagrange, Newton Gregory Forward, dan Newton Gregory Backward terdapat pada derajat 2 di setiap metode interpolasi dibandingkan dengan derajat 4,5,10, dan 20. Hal ini menunjukkan bahwa derajat 2 merupakan derajat yang optimum ketika digunakan untuk menginterpolasi dengan menggunakan metode Lagrange dan Newton Gregory daripada derajat 4,5,10, dan 20.

\section{Saran}

Mengacu pada hasil penelitian ini, penulis menyarankan beberapa hal sebagai berikut.

1. Untuk penelitian selanjutnya, diharapkan menggunakan metode lain selain metode Lagrange dan metode Newton Gregory.

2. Untuk penelitian selanjutnya dapat menggunakan software selain Microsoft Excel.

\section{REFERENSI}

Astuti, L. W., Sudarwanto, Ambarwati, L., 2018, Perbandingan Metode Lagrange dan Metode Newton pada Interpolasi Polinomial dalam Mengestimasi Harga Saham. Jurnal Matematika dan Terapan, 2(1) : 25-35

Hakimah, M., Kurniawan, M., Muhima, R. R., 2020, Pemodelan Jumlah Kasus Baru Covid-19 di Masa Kenormalan Baru Menggunakan Metode Pencocokan Kurva, Seminar Nasional Sains dan Teknologi Terapan VIII 2020, 361-368

Herstein, I.N., 1996, Abstract Algebra Edisi ke-3, Prentice-Hall, Inc, New Jersey

Rahmatullah, I., 2020,Jaminan Hak Kesehatan Pekerja Work From Office Selama Masa PSBB Covid-19, ADALAH Buletin Hukum dan Keadlian, 4(1) : 57-62

Satuan Tugas Penanganan Covid-19 Republik Indonesia, 2020, [ONLINE], Tersedia : https://covid19.go.id/peta-sebaranhttps://covid19.go.id/peta-sebaran (diakses pada tanggal 13 November 2020 pukul 19.58)

Wahyuni, R., Simamora, I., 2019, Penerapan Metode Polinom Newton Gregory Maju dan Polinom Newton Gregory Mundur dengan Metode Hamilton-Perry dalam Memprediksi Jumlah Penduduk Sumatera Utara, Curere, 3(2) : 48-57

Warmansyah, J., Hilpiah, D., 2019, Penerapan Metode Fuzzy Sugeno untuk Prediksi Persediaan Bahan Baku, TEKNOIS, 9(2) : 12-20 